\title{
Verbalization of the concept "old" in the English and Russian folklore linguistic worldview
}

\author{
Svetlana S. Sotnikova ${ }^{1, *}$ \\ ${ }^{1}$ Kursk State University, Language Theory and Methodology of Foreign Languages Teaching Department, Radischeva Street, 33, \\ 305000, Kursk, Russia
}

\begin{abstract}
The paper presents the results of the study of the vocabulary constituting concept 'old' in the folk linguistic worldview based on the material of the English and Russian folk lyrics. The author makes an attempt to find ethnic peculiarities of this vocabulary taking into account the frequency of the words usage and their syntagmatic relations in the texts of the songs. The paper provides some examples of the chosen vocabulary functioning in the English and Russian folklore. The novelty of this study stems from the source material used - the paper is the first one to present a comparative research of verbalizing the concept 'old' in English and Russian folklore texts. It is also relevant as it identifies certain specificity of the mentality of two ethnoses and figures out the ways of its reflection in the English and Russian folklore linguistic worldview.
\end{abstract}

\section{Introduction}

The interrelation between the language and the mentality of the people speaking the language has already been studied and proved by many scholars. The lexis of each language divides the extralingustic reality with its specific ways of referring to the same notions differently in different languages. At the same time, the national specificity of the language reveals itself in words. According to N.F. Alefirenko, behind the word in its acoustic or graphic form, there is a fragment of a living image from a particular ethnoculture [1].

The language of folklore has its cultural significance as it is a product of folk art and, at the same time, it reflects the social features of the society and the national worldview of the ethnos. Since the XX century such scholars as J. Bartminski, V. Propp and A. Chrolenko have been elaborating on diverse theoretical and practical methods of researching folklore language [2-4]. It has been emphasized in their works that folklore is a creative reflection of our life and one of the ever-living sources of research on culture of any nation and invaluable matter for carrying on thorough investigation of national history, language, and mentality. The oral folk art contains the ethnic model of the people participating in its creation. The oral folk art is considered to be a reflection of historical and cultural realities. Folk songs can give important information about the language and the ethnos as their words, according to A. Chrolenko [4], are determined by the people's way of life, outlook and national psychology, their culture and history.

We have already analyzed different fragments of folklore language in Russian and English folk songs and identified the ethno-cultural peculiarities of these fragments. For example, in our previous research we focused on the cluster "home" in Russian and English folklore lyrics and the representation of concept 'man' in English folk songs [5-6]. This article is aimed at studying the concept 'old' in English and Russian folk songs lyrics, with a focus on the frequency of usage of the words naming the concept and their syntagmatic relations in the texts of the songs. The main objective of the paper is to perform a comparative analysis of ways of verbalizing the concept "old" in the English and Russian folk lyrics. The object of the research is the vocabulary of the texts of English and Russian folk songs. There are many studies on the problem of verbalization of fragments of linguistic worldview based on different source material. For example, some of the latest research is devoted to the verbalization of the concept of "Vigilante Justice" in Agatha Christie's creative work; the cross-cultural overlapping of the emotion "grief and suffering" in the Russian and English languages; the verbalization of emotions in texts of economic mass media [7-9].

The novelty of this study stems from the source material used - no previous study has investigated the chosen concept in the texts of folk songs. The paper is the first one to present a comparative research of verbalizing the concept 'old' in English and Russian folklore texts. It is also relevant as it is necessary to identify certain specificity of the mentality of two ethnoses and to figure out the ways of its reflection in the English and Russian folklore linguistic worldview. The concept 'old' was chosen as a phenomenon that is a significant component of any nation's spiritual culture.

\footnotetext{
* Corresponding author: svetlana-s-sotnikova@yandex.ru
} 


\section{Material and methods}

The research included the Great Russian Folklore Songs collected and published by A. Sobolevsky (Sob.), the Songs collected by P.V. Kireevsky (Kir.) (741 texts in total) and Cecil Sharp's Collection of English Folk Songs (Sh.) (1042 texts) [10-12].

The research is conducted in keeping with the cross-cultural linguafolkloristics - a branch of folkloristics based on comparing folklore language phenomena of two or more languages [13].

The study requires a complex of research methods, both traditional linguistic ones and the method of computer aided text study [14], which is necessary to make up wordlists and identify the given lexemes and concordance sets.

The leading methods used were linguistic description and complex comparative analysis of the texts. The two methods implied direct observation on the lexis and selection, analysis, systematization of the factual material.

We also used the methods created by Kursk folkloristics school (such as the dominant and cluster analyses, and the application of the dictionary entries obtained as a result of compressing the concordances) [15].

The dominant analysis, the frequency of the word usage and the syntagmatic relations of the lexemes in the texts of the songs provided the information on what constitutes the concept 'old' in the English and Russian folklore linguistic worldview.

\section{Results and Discussion}

The analysis of the corpus of the English folk songs distinguished 376 cases of word usage of the lexeme old in combination with 91 words it modifies. In accordance with the object the adjective describes, we classified all the words into two groups: living beings and non-living things.

The results of the investigation allow us to conclude that the names of living beings constitute a bigger group of words described as old. The most frequently used lexeme among them is man with 66 word usages (w.u.). For example:

Then up spoke the captain of the ship,

And a fine old man was he $<$ Sh. 46, C>;

The drum and fife is her (or my) delight And a merry old man is mine $O<S h .108, G>$;

Now she went and got six marrow-bones And she made him suck them all, And that made the old man blind

Till he couldn't see any at all $<$ Sh. 207,A>.

Then goes the word woman (20 w.u.). For example: And he left the old woman to stay at home, $O$ what a good man was he, etc. $<$ Sh. 191, A>;

A man and old woman lived under the hill,
And that you can very well see $<$ Sh. 205>;

There was an old woman in our town, In our town did dwell,

And she loved her husband dearly

But another man twice as well $<$ Sh. 207,A $>$.

It is necessary to mention that the lexemes naming the male human beings prevail over those naming females (lord (1 w.u.), farmer (1 w.u.), miser (5 w.u.), shipmate (1 w.u.), boatman (4 w.u.), boxer (1 w.u.), housekeeper (2 w.u.), father (3 w.u.), clerk (1 w.u.), king (2 w.u.), cobbler (1 w.u.), daddy (2 w.u.), miller (1 w.u.), master (1 w.u.) and wife (3 w.u.), grandmother (1 w.u.), mammy (1 w.u.), mother (8 w.u.), maid (1 w.u.). For example:

When the old lord he came home

Inquiring for his lady $O<S h .34, K>$;

There was an old farmer in New York did dwell,

Hurrah, my boys, hurrah, hurrah,

He had an old wife and he wished her in bell,

Hurrah, my boys, hurrah, hurrah $<$ Sh. 42, C>;

It was of an old boatsman in Dover he did dwell

And he had a little wife and he loved her so well $<$ Sh. 189>;

It's of an old miser in London did dwell,

He had but one daughter, most beautiful girl $<$ Sh. 91,A>;

There's old Mother Wick to Bob,

Old Grandmother Squid to Squob $<$ Sh. 313,A $>$;

I mean to have one of your family now,

Fol dol diddle dum day,

'Tis not your oldest son I do crave,

Your scolding old wife

I mean for to have $<$ Sh. $42, B>$.

Also, the adjective old modifies some people giving only their names: Nell (4 w.u.), Rosin (6 w.u.), Hannah Sutton (1 w.u.), Hannah Dan (1 w.u.), Nick (1 w.u.), John (1 w.u.), Johnny (1 w.u.), Reynard (1 w.u.), Ram(1 w.u.). For example:

Put old Sir John in another fine bowl,

And you'll pull down the strongest man $<$ Sh. 247,A>;

Says the old Cole to the young Cole,

'Tis the old Cole of all $<$ Sh. 259,A $>$;

In steps old Hannah Sutton,

She got a-roasting of mutton $<$ Sh. 313,A>.

The common nouns were also divided into two groups: lifeless and animate objects. The lifeless objects are represented by the following lexemes: door ( 3 w.u.), bag (3 w.u.), cottage (1 w.u.), bone (1 w.u.), hide (2 w.u.), mitten (1w.u.), curtain ring (1 w.u.), button (1 w.u.), spoon (1 w.u.), sheepskin (1 w.u.), lime bag (1 w.u.), lock (2 w.u.), jug (1 w.u.), stay of hay (2 w.u.), 
beer (1w.u.), chop (1 w.u.), church (1 w.u.), coat (3 w.u.), den (1 w.u.). It is worth mentioning that these lexemes have a very low word usage (1-3). For example: And if ever I call this way again, love, remember the old barn door $<$ Sh. 43, D >;

Foggy long miles I travelled this day $A>$;

And a little old cottage I spied in the way $<$ Sh. 107,

An old lime bag will do, says Joan to Jan $<$ Sh. 314>.

Besides, some plants and trees are described as old in the lyrics: nettle (4 w.u.), oak tree (4 w.u.), ashen tree (3 w.u.), apple tree (2 w.u.) and hollow tree (1 w.u.):

Old apple tree, we'll wassail thee $<$ Sh. $373, \mathrm{~L}>$;

The first thing they came to was an old hollow tree Said the sailor to the soldier: This my pulpit shall be $<$ Sh 376 A $>$;

The cup it is made of the good old ashen tree, And so is our beer of the best barley $<$ Sh. 373,A $>$.

The old animate objects are represented by different animals (domestic and wild ones): cow (8 w.u.), cat (1 w.u), $\operatorname{dog}(1$ w.u.), mare (8 w.u.), sow (6 w.u.), fox (3 w.u.) calf (1w.u.), bull (1 w.u.), bear (1 w.u.), ewe (1 w.u.), horse (17 w.u.):

Six old cows as they was a-roaring,

Seven old calves as they cast afore them,

Eight old bulls and they was blaring,

Nine old whores and they was quarreling,

Ten old cows as they was roaring,

Eleven old mares and they was bawling,

Twelve old bears and they was roaring $<$ Sh. 337>;

O up flies the kite, and down falls the lark $O$, Aunt Ursula Birdhood she had an old ewe, And she died in her own park $O<$ Sh. 374>.

In three contexts, the adjective old describes birds: goose (5 w.u.), crow (2 w.u.), hawk (3 w.u.):

O ho, said his wife, you're a silly old goose

To kill your old sow and not care a mouse $<$ Sh. 332,

$\mathrm{A}>$;

Jolly old hawk and his wings was grey,

Now let us sing, who shall wing the girl but me

$<$ Sh. 337>;

Ah then the tailor said: Fetch me an arrow and my bow

That I may go and shoot the nasty old carrion crow $<$ Sh. 332,B $>$.

Only once fish is characterized as old:

What have I done with the old herring's head?

$<$ Sh. 345,B>

Twice the folklore character meditates on time and age saying:
The old year is gone and the new year is come, And all the jolly soldiers are beating on the drum,

So I wish you a happy New Year <Sh. 368,A>;

We never shall live to see old age,

Our lives shall not endure $<$ Sh. 369>.

The heroes may call their country 'old': we figured out 28 cases when England is described as old:

How she hold it in her hand,

Saying: The flower of old England

Shall never detain me long $<$ Sh. 32>.

Once Britannia and Ireland have the attribute old:

For the old Britannia of fair London town

Has sunk to the bottom of the sea $<$ Sh. 38, L>;

It was early, early all in the Spring,

The birds did whistle and sweetly sing,

Changing their notes from tree to tree

And the song they sang was old Ireland free $<$ Sh. $309>$.

There are several cases when the adjective functions in some offensive expressions: old bitch (3 w.u.), old whore (1 w.u.) and old devil (3 w.u.), for example:

It was of a farmer in Cheshire did dwell,

And by the old devil was known very well $<$ Sh. 42,

$\mathrm{A}>$;

I don't want thee nor thy son Jack,

But it's thy old bitch of a wife I'll have $<$ Sh. 42, A $>$.

In three contexts, the word old is parallel to the adjective young:

The old and young likewise,

Until at last she cried, I am undone <Sh. 37>.

Having investigated Russian folk songs, we singled out 206 cases of the word usage of the adjective staryi (i.e. 'old') in its different word forms. Practically in most of the contexts (in 179 cases) it functions as a substantivized adjective:

Mne-to batushka nakazyval: "Ty ditya, moyo dityatko,

Kak staryi idet - poklonis', Molodoy idet prikhoronis'/

'My father said to me: You, my child, bow down when an old is coming up and hide when a young one is' $<$ Sob. 2. 57>;

So starym ya stoyala, s molodym rassuzhdala ..."

'I was standing with an old and I was talking with a young' <Sob. 2, 560>.

We identified 49 word usages of the expression staryi muzh (i.e. 'an old husband'):

"Ty, staryi muzh, - pogubitel' moy:

Pogubil ty moyu golovushku ... I

"You, my old husband, are my blighter:

You have ruined my head (Sob. 2, 57); 
U starogo muzha zhit' tyazhelo/

It is hard to live with an old husband $<$ Sob. 2, 313 $>$.

The most frequent action associated with an old man is to marry, in most cases a young girl is made to marry an old man against her will, which brings her a lot of suffering.

Ona slushala-vyslushivala, kak v vysokom vo tereme Krasnaya devitsa plakala za starogo muzha iduchi!/ 'She heard as in a high terem a beautiful young girl was crying when she was getting married an old husband' <Sob. 2, 356>;

Otdayut tebya za starogo starika,

Staryi starichenochka,On ne pustit pogulyat'।

'You are got to marry an old man

He will not let you go for a walk< <ob. 2,446>.

Russian folk songs describe the actions typical of the character - an old husband. He can plavat' 'swim' (3 w.u.), spat' 'sleep' (1w.u.), probuditsya 'wake up' (1 w.u.), sidet' 'sit' (3 w.u.), protyanut' nogi 'die' (1 w.u.), polzat' 'crawl' (1 w.u.), khodit' 'go' (1 w.u.), prihkodit' 'come' (3 w.u.), igrat' na guslyahk 'play the gusli' (1 w.u.), svatat'sya 'ask in marriage' (1 w.u.). For example:

Polzet moy star iz-pod lavochya I

My old one is crawling out under the bench

$<$ Kir. 1237 (53)>;

Uzh kak staryi muzh vzmolilsya mne:

'Ty, dusha moya, zhonushka!'”

My old husband begged me:

'You, my soul, are my wife!' <Kir. 1313 (37)>;

Kakovo staryi plavaet!/

So well the old swims! <Kir. 1316 (3)>.

The wife of the character can molit' 'prey' ( 1 w.u.), budit' (3 w.u.), terpet' 'tolerate' (1 w.u.), zhit' 'live with' (1 w.u.) him. The other folk heroes: do not love him 'ne lubit' (1 w.u.), nanimat' 'engage' (1 w.u.), odevat' 'dress' (1 w.u.), lubit' 'love' (3 w.u.), tselovat' 'kiss' (1 w.u.), dostavat'sya (3 w.u.):

Pro menya, mladu, rasskazyvayut,

Bud-to ya, mlada, starogo ne lublu /

They tell about me, a young,

that I, young, do not like the old $<$ Sob. 3, 144>;

Ya ne znauy, s kem mne vestku pereslat':

Uzh kak starogo nanyat'।

I don't know who to give a massage with :

How to engage the old <Kir. 1333 (5)>

Besides the noun muzh 'husband' the adjective staryi is also combined with the noun starik 'old man' (15 w.u.).

Posmotruy na stara starika, kakovo staryi plavaet /

I will have a look the way the old man is swimming <Sob. 3, 134>;

We identified only 9 cases when baba 'the woman' is old.

S staroy baboyu voditsya - hkudoy slabushki dobit'syal

To deal with an old women is to gain a bad reputation $<$ Kir. 1396 (2) $>$;

The following nouns modified by the word old have a low word usage (1-3): sudarushka 'madam', babushka 'grandmother', matushka 'mother', dolg 'debt', lubov' 'love', guzh 'a loop for a horse's collar', zakon 'law'. For example:

Staraya babushka govorit: "K nam plutovku vedut”/ An old grandmother says, 'A little rogue is being brought to us" < Kir. 1284 (8)>;

Ty vosstan', vosstan', stara matushka,

Baska-hkorosha, svet-Mikhailovna /

Arise, arise the old mother, Baska Mihkailovna!

$<$ Kir. 1340>;

Vidno chert uvolok za staryi dolg /

A devil might have taken him for an old debt

$<$ Sob. 3, 143>;

Po staromu zakonu chetyre poklona /

According to the old law it is four bows <Kir. 1186 (2)>.

In Russian folk songs, we also identify 3 cases when the adjective staryi is combined with the noun chert 'devil' to name an old man or an old woman:

Vse eto ot svekrovki, ot staroi chertovki /

All this is from the mother-in law, from an old devil

$<$ Sob. 2 74>;

Vse eto ot svekra, ot starogo cherta

/ All this is from the father-in law, from an old devil

$<$ Sob. 3 502>.

The adjectives associated with the lexeme staryi 'old' are udushlivyi 'smudge' (5 w.u.), uvyazhchivyi 'bothersome,' (1 w.u.), urodlivyi 'ugly' (1 w.u.), ne udaloy 'not daring' (1 w.u.), ne druzhlivyi 'unfriendly' (1 w.u.):

Ne raven chert dostanetsya,

Libo staroe ne druzhlivoe,

Libo mlado spesivoel

It may fall to my lot,

Either old and not friendly,

Or young and conceited <Kir. 1316 (3)>

Zaydu v tikhuyu besedu, vo bisedu,

Vo bisede sidit staryi, sidit staryi,

Sidit staryi ne udaloy/

I will enter an arbor, an arbor,

An old is sitting there, there,

An old is sitting not daring <Kir. 1318 (5)>

Also, the following words with the same root 'star' were identified in the Russian folk texts: starost 'old age' (11 w.u.), starik 'old man' (22 w.u.), starukha 'old woman' (2 w.u.):

Ya starosti ne boyus'/

I am not afraid of old age <Sob. 3, 239>; 
Ah ty starukha sheptukha, ne zabyla li menya!/

Ah you an old woman - whisperer,

have you forgotten me! <Sob. 3, 129>;

Oy, spasibo, zhena, Ne zabyla starika /

Oh, thank you my wife,

You have not forgotten the old $<105>$

Mne izyumu-to khochetsya,

Starika lubit' ne khochetsya /

I would like to eat some raisin,

But I wouldn't like to love an old man <Kir. 1204

(20)>.

\section{Conclusion}

Thus, the analysis allows us to conclude that the concept 'old' is inherent in both English and Russian folk songs lyrics. At the same time, the quantitative analysis showed the difference in the number of the word usage, which may indicate a different degree of importance of this phenomenon in folklore texts. We see that the common ground for two linguistic cultures is the old age of the character 'an old man', 'an old women', 'an old mother', 'an old father'. We can also notice that the English list of words is much richer and includes objects from different spheres of life. In the Russian folk lyrics, there prevails the substantivized adjective 'staryi', which is very rare in the English songs. The results of the observations and the analysis lead us to the conclusion about the cultural ethnic specificity of the studied concept in the linguistic worldview of two peoples.

\section{References}

1. N.F. Alefirenko, X L. Jour. 08.03, 2-18 (2015)

2. J. Bartminski, On folklore language (Wroclaw, Wwa, 1973)

3. V.Ya. Propp, Folklore and Reality (Nauka, Moscow, 1989)

4. A.T. Chrolenko, Semantics of Folklore Words (VSU, Voronezh, 1992)

5. S.S. Sotnikova, Comparative Studies 15, 68-72 (2018)

6. S.S. Sotnikova, Scientific Notes 2(34), 101-110 (2015)

7. S. Argashokova, M. Mikaelyan, A. Zgonnikova, I. Zueva, SHS Web of Conferences 50, 01106 (2018)

8. N.N. Olomskaya, R.V. Patyukova, T.A. Kudinova, L.I. Demina, M.N. Cherkasova, X L. Jour. 11.01, 242-250 (2018)

9. E.S. Smakhtin, I.I. Klimova, V.S. Arkhipova, K.V. Andrievskii, O.O. Shalamova, N.A. Sidorova, X L. Jour. 11.03, 103-113 (2018)

10. A.I. Sobolevsky, Great Russian Folklore Songs (State Printing-house, St. Petersburg, 1897)

11. P.V. Kireevsky, Folk Songs (Russian Folklore Society, Moscow, 1917)

12. C. Sharp, Collection of English Folk Songs (Oxford University Press, L., 1974)

13. A.T. Chrolenco, Introduction into Linguofolkloristics (Flinta, Nauka, Moscow, 2010)

14. A.T. Chrolenco, Comparative and Cross-Cultural Linguofolkloristics (Kursk State University, Kursk, 2005)

15. A.T. Chrolenko, Philological Region Studies 2(8), 46-50 (2012). 